\title{
Hybrid photosynthesis-powering biocatalysts with solar energy captured by inorganic devices
}

\author{
Tian Zhang and Pier-Luc Tremblay* (1)
}

\begin{abstract}
The biological reduction of $\mathrm{CO}_{2}$ driven by sunlight via photosynthesis is a crucial process for life on earth. However, the conversion efficiency of solar energy to biomass by natural photosynthesis is low. This translates in bioproduction processes relying on natural photosynthesis that are inefficient energetically. Recently, hybrid photosynthetic technologies with the potential of significantly increasing the efficiency of solar energy conversion to products have been developed. In these systems, the reduction of $\mathrm{CO}_{2}$ into biofuels or other chemicals of interest by biocatalysts is driven by solar energy captured with inorganic devices such as photovoltaic cells or photoelectrodes. Here, we explore hybrid photosynthesis and examine the strategies being deployed to improve this biotechnology.
\end{abstract}

Keywords: Hybrid photosynthesis, Biocatalyst, Photocatalyst, Photobioelectrochemical cell, Microbial electrosynthesis, Photovoltaic, Biofuel, $\mathrm{CO}_{2}$ reduction, Solar energy

\section{Background}

Fossil fuels still represent today more than $80 \%$ of all the energy sources employed in the world [1]. Besides being used as fuels, petroleum, coal, and natural gas are also major precursors for the industrial production of a large range of chemicals [2]. Fossil fuels are finite resources, and their indiscriminate utilization causes significant harmful effects on the environment, such as oil spill and water pollution. One of the major negative environmental impacts of fossil fuels is the release of large quantity of $\mathrm{CO}_{2}$ in the atmosphere representing $65 \%$ of all the greenhouse gas emissions responsible for anthropogenic global warming [3].

Because of the critical disadvantages associated with the extensive usage of fossil fuels, the sustainable and economically viable production of fuels and other chemicals from $\mathrm{CO}_{2}$ and renewable energy sources has become one of the main technological challenges of our time. Besides being the main driver for climate changes [4], $\mathrm{CO}_{2}$ is also a renewable resource and a major

*Correspondence: pierluct@whut.edu.cn

School of Chemistry, Chemical Engineering and Life Science, Wuhan

University of Technology, Wuhan 430070, People's Republic of China carbon source for living organisms. In terms of renewable energy, sunlight is very abundant with ca. 885 million TWh of power reaching the Earth surface every year. According to the International Energy Agency (IEA), this represents 3500 times the total quantity of energy that would be used by human in 2050 [5, 6]. Consequently, it is sensible to undertake research efforts aiming at powering $\mathrm{CO}_{2}$ reduction by means of solar energy at industrial scale, which is currently the pursuit of multiple research groups around the world.

Solar energy has two important constraints that must be considered for the elaboration of novel technologies: its intermittent nature and its low average terrestrial power density (global mean of $170 \mathrm{w} \mathrm{m}^{-2}$ ) [7, 8]. Thus, it is of great importance to conceive systems with optimal efficiency for the capture of solar energy and its subsequent conversion in fuels that are easy to store and use.

Over billions of years, evolution has developed natural photosynthesis to convert solar energy into chemical energy to power living cells [9]. Until now, many of the bioproduction processes employing living organisms as catalysts for the synthesis of fuels or other chemicals have relied on natural photosynthesis to acquire the necessary energy. This can be done directly by means 
of photosynthetic plants, algae, microalgae, or bacteria, converting inorganic carbon molecules into products [10-14]. Alternatively, this can also be done indirectly via the oxidation or fermentation of organic carbon molecules derived from photosynthetic biomass by nonphotosynthetic microorganisms [15-19]. However, natural photosynthesis has evolved over time to facilitate the reproductive success of photosynthetic organisms and not for high efficiency in terms of conversion of solar energy-to-biomass or solar energy-to-specific chemicals [7]. For instance, sugarcane fermentation for the production of ethanol has an average solar energyto-product conversion efficiency of only $0.2 \%$, whereas the efficiency of photosynthetic production of oil by microalgae is higher but still very low at $1.5 \%$ [20-23]. Because of this limited solar energy conversion efficiency, which also has a negative impact on agricultural yields, recent efforts have been deployed to engineer photosynthetic organisms via different synthetic biology strategies to improve solar energy-to-biomass conversion [24-28].

In comparison with natural photosynthesis-based processes, artificial photosynthesis systems where either photoelectrochemical cells or solid-state photovoltaic apparatuses capture solar energy to drive fuel production are more efficient $[20,29,30]$. This is mainly due to the high efficiency of light-absorbing materials employed. For instance, photovoltaic cells have a solar energy-toelectricity conversion efficiency varying from 16 to $21 \%$ in respect of widely used Si panels to greater than $40 \%$ in the case of cutting-edge multijunction cells $[8,31]$. To date, some of the best artificial photosynthesis systems for fuel production can reach solar energy-to- $\mathrm{H}_{2}$ conversion efficiency ranging from ca. 12 to $18 \%$ [32-38].

Artificial photosynthesis has been used to drive the reduction of $\mathrm{CO}_{2}$ into fuels. Photoelectrochemical reactors developed until now for this purpose produced mostly $\mathrm{C} 1$ compounds such as carbon monoxide, methane, methanol, formaldehyde, and formate [39, 40]. One major advantage of biological systems over inorganic apparatuses is their capacity to synthesize a large range of long-chain carbon molecules that can be used as fuels with preferable physicochemical properties or for other chemical applications. Recently, hybrid photosynthesis systems have claimed advantages of both the metabolic versatility of microorganisms and the efficiency of inorganic solar energy capture devices to drive the reduction of $\mathrm{CO}_{2}$ into biofuels and other multicarbon compounds $[30,41,42]$. This novel approach is showing promising potentials that could lead to industrial-scale applications in the near future. The purpose of this review is to discuss the recent advances made in the field of hybrid photosynthesis today and to highlight the challenges associated with this technology.

\section{Principle of hybrid photosynthesis}

During hybrid photosynthesis, solar energy is captured by inorganic sunlight absorbers before being used by biological catalysts for driving $\mathrm{CO}_{2}$ reduction. Hybrid photosynthesis systems are diverse since they can couple different types of inorganic solar energy capture devices such as solid-state photovoltaics, photoelectrodes, and photocatalyst nanoparticles or several biological catalysts, including autotrophic bacteria or archaea and enzymes.

\section{Powering MES with solid-state photovoltaic}

A promising strategy for achieving efficient and productive hybrid photosynthesis process is to power a microbial electrosynthesis (MES) reactor with solid-state photovoltaics (PVs) (Fig. 1a) [29, 43, 44]. The principle behind MES is that autotrophic microbes use reducing equivalents generated by an electrochemical reactor to reduce $\mathrm{CO}_{2}$ into biofuels or other chemicals of interest $[45,46]$. MES reactors developed until now have different configurations, but the most common one includes an anode and a cathode separated by an ion-exchange membrane and connected by an electric circuit [41]. Protons and electrons are generated by oxidation reactions at the anode, such as water splitting, and the biological oxidation of wastewater or sulfide waste [43, 47-52]. Electrons flow through the electric conduit from the anode to the more negative cathode, while protons migrate through the ion-exchange membrane. Electrons and protons are then acquired by the autotrophic biocatalyst in the cathodic chamber where it reduces $\mathrm{CO}_{2}$. MES processes are driven by an external source of electricity that can be generated via renewable energy resources such as wind and solar.

Because of their metabolic versatility, the different biocatalysts employed for MES until now have been shown to produce a large range of products including $\mathrm{C} 1 \mathrm{com}$ pounds such as methane and formate as well as multicarbon molecules such as acetate, butyrate, 2-oxobutyrate, propionate, ethanol, 1-butanol, isobutanol, 3-methyl1-butanol, and wax esters [41, 52-56]. MES biocatalysts are diverse and comprise both pure cultures as well as mixed communities [45]. When mixed communities are employed for MES, acetogens mainly producing acetate by using $\mathrm{CO}_{2}$ as electron acceptor via the Wood-Ljungdahl pathway and methanogens generating methane from $\mathrm{CO}_{2}$ often become the dominating populations [50, 57-61]. There are many examples of pure culture-driven MES reactors including systems where the biocatalyst 




was an acetogen, a $\mathrm{Fe}^{2+}$-oxidizing bacterium, the ammonia-oxidizer Nitrosomonas europaea, the electrogenic bacterium Geobacter sulfurreducens, or the bioplastic producer Ralstonia eutropha [44, 49, 53, 62-72].

For PV-driven MES, the MES reactor is connected via external wires to an autonomous solid-state PV cell. One of the main reasons why PVs are more efficient at converting solar energy than natural photosynthesis is that they have a larger light absorption range that can stretch from the ultraviolet to the near-infrared [7]. Because of technological innovations and manufacturing scale-up, PV deployment for domestic or industrial usages has increased significantly in the last decade, while costs have decreased concomitantly [73]. In terms of efficiency, market leader multicrystalline $\mathrm{Si}$ (multi-Si) PVs can convert $21 \%$ of the received solar energy into electricity [8]. Currently, the most efficient PV is a four-junction system (GaInP/GaAs//GaInAsP/GaInAs) still at laboratory scale, which can convert $46 \%$ of the received solar energy into electricity [74].

The coulombic efficiency for the production of acetate from $\mathrm{CO}_{2}$ by $\mathrm{MES}$ is often between 80 and $90 \%$ when efficient biocatalysts for MES such as the acetogen Sporomusa ovata are employed $[43,63,65]$. Thus, the energetic efficiency of the MES reactor for acetate production could be theoretically around $47 \%$ assuming a coulombic efficiency of $85 \%$ and a whole electrochemical cell voltage of $-2 \mathrm{~V}$ [75]. The theoretical, optimal equilibrium potential in an electrochemical cell for $\mathrm{CO}_{2}$ reduction into acetate at the cathode and water splitting at the anode should be $-1.1 \mathrm{~V}$, but because of electrode overpotentials associated with every electrochemical reaction, the practical whole cell voltage should be higher by several hundred millivolts $[46,76]$. Thus, powering a MES reactor for acetate production with multi-Si PV or with four-junction PV could result in hybrid photosynthesis systems with solar energy-to-acetate conversion efficiency of ca. $9.9 \%$ or ca. $21.6 \%$, respectively (Table 1 ).

Recently, Liu et al. developed a MES system for the production of polyhydroxybutyrate (PHB) and $\mathrm{C} 3-\mathrm{C} 5$ alcohols from $\mathrm{CO}_{2}$ with a Co-Pi anode, a Co-P alloy cathode, and Ralstonia eutropha as the microbial catalyst (Fig. 1a) [77]. This electrode tandem was employed because it significantly lessens the overpotential required for water splitting and it is also nontoxic for bacteria. $R$. eutropha was used as the biocatalyst because it can produce significant quantity of PHB from $\mathrm{CO}_{2}$ and it can also be genetically engineered [78, 79]. Interestingly, relatively good energy efficiencies of $42 \%$ for PHB, $39 \%$ for isopropanol, and 27\% for $\mathrm{C} 4$ and $\mathrm{C} 5$ alcohols were achieved with this MES system. Based on these results, the authors calculated that powering their MES reactor with a PV device that has a solar energy-to-electricity conversion efficiency of $18 \%$ would result in a hybrid photosynthesis 
Table 1 Examples of hybrid photosynthesis system with microbes as biocatalyst

\begin{tabular}{|c|c|c|c|c|}
\hline System & Light harvester & Microbe & Comments & References \\
\hline$P V+M E S$ & Multi-Si PVa & S. ovata & $\begin{array}{l}\text { Graphite electrodes } \\
\text { Water splitting } \\
\text { Produces acetate and 2-oxobutyrate } \\
\text { Efficiency }: 8.5-9.9 \%\end{array}$ & {$[43]$} \\
\hline$P V+M E S$ & Multi-Si PV & R. eutropha & $\begin{array}{l}\text { Co-Pi anode/Co-P cathode } \\
\text { Water splitting } \\
\text { PHB efficiency: } 7.6-8.9 \% \\
\text { C3-C5 alcohols efficiency: } 7.1-8.3 \%\end{array}$ & {$[77]$} \\
\hline PBEC & $\begin{array}{l}\text { Si nanowire photocathode } \\
\mathrm{TiO}_{2} \text { photoanode }\end{array}$ & S. ovata & $\begin{array}{l}\text { Water splitting } \\
1.2 \mathrm{~g} \mathrm{~L}^{-1} \text { day }^{-1} \text { acetate } \\
\text { Efficiency: } 0.38 \% \\
\text { PHB, } n \text {-butanol and isoprenoids were produced } \\
\text { from acetate in a } 2 \text { nd reactor }\end{array}$ & {$[98]$} \\
\hline PBEC & $n^{+} / p$-Si photocathode & M. barkeri & $\begin{array}{l}\text { Pt gauze anode } \\
\text { Water splitting } \\
5.86 \mathrm{~mL} \mathrm{day}^{-1} \mathrm{CH}_{4}\end{array}$ & {$[90]$} \\
\hline PBEC & $\begin{array}{l}\text { p-InP photocathode } \\
n-\mathrm{TiO}_{2} \text { nanowire/FTO } \\
\text { photoanode }\end{array}$ & M. barkeri & $\begin{array}{l}\text { Water splitting } \\
0.58 \mathrm{~mL} \mathrm{day}^{-1} \mathrm{CH}_{4}\end{array}$ & {$[90]$} \\
\hline PC & CdS nanoparticles & M. thermoacetica & $\begin{array}{l}\text { Cysteine as } \mathrm{e}^{-} \text {donor } \\
0.48 \mathrm{mM} \mathrm{day}^{-1} \text { acetate }\end{array}$ & {$[101]$} \\
\hline$P C$ & $\begin{array}{l}\mathrm{CdS} \text { nanoparticles } \\
\mathrm{TiO}_{2} \text { nanoparticles }\end{array}$ & M. thermoacetica & $\begin{array}{l}\text { Z-scheme } \\
\text { Water splitting } \\
\text { Cysteine as } \mathrm{e}^{-} \text {shuttle } \\
\text { Cocatalyst } \mathrm{MnPc} \\
1.2 \mathrm{mM}^{-1} \text { day }^{-1} \text { acetate }\end{array}$ & {$[102]$} \\
\hline
\end{tabular}

PV photovoltaic, MES microbial electrosynthesis, PBEC photobioelectrochemical cell, $P C$ photocatalyst-driven system

a Coupling of the PV with the MES system has not been tested experimentally. Solar energy-to-electricity conversion efficiency of multi-Si PV was assumed to be $18-21 \%$

b Efficiency refers to solar energy-to-product conversion efficiency

system with a solar energy-to-chemicals conversion efficiency of 7.6\% for PHB and 7.1\% for C3-C5 alcohols.

One advantage of MES in the context of hybrid photosynthesis is that physical contact between the microbial catalyst and the cathode may reduce the electrical energy and electrode overpotentials required for the generation of reducing equivalents at the cathode by the electrochemical reactor, making the whole system more efficient. For instance, it has been shown that the presence of microbes in the cathodic chamber of a MES reactor can accelerate the evolution of $\mathrm{H}_{2}$, which is often the main electron shuttle in this type of system [80, 81]. Furthermore, it has been suggested that electrons can be transferred directly from the cathode to microbes without the need for electron shuttles, which is an electrontransfer mechanism that would also require less electrical energy $[43,68,71]$.

\section{Coupling photovoltaic with an electrolyzer to produce $\mathrm{H}_{2}$ or $\mathrm{CO}$ for gas fermentation}

As an alternative to MES, it may be advantageous in terms of efficiency and productivity to assemble a hybrid photosynthesis system, where solid-state PVs are powering an electrolyzer splitting water to provide $\mathrm{H}_{2}$ to a gas fermentation reactor for the reduction of $\mathrm{CO}_{2}$ by an autotrophic biocatalyst (Fig. 1b) [41]. Nowadays, scaleup commercial electrolyzers using proton-exchange membrane (PEM) have energetic efficiencies between 65 and $70 \%$ [82]. This means that if an acetogen or another microbial catalyst converts ca. $80-90 \%$ of electrons from $\mathrm{H}_{2}$ into acetate or other products, the solar energy-tospecific product conversion efficiency of a system combining multi-Si PVs, a PEM electrolyzer, and a $\mathrm{H}_{2}: \mathrm{CO}_{2}$ gas fermentation reactor could be 11-13\%. Compared with a PV-MES approach, the main advantage of this system is that the specialized electrolyzer can maintain a high flux of reducing equivalents toward the gas bioreactor, preventing productivity bottleneck associated with MES [41].

Electrolyzers powered by PVs could also be used to reduce $\mathrm{CO}_{2}$ into $\mathrm{CO}$, which can then be fed to a gas fermentation reactor for the production of biofuels by acetogens [82]. This approach is particularly advantageous since $\mathrm{CO}$-rich gas feeds are required by acetogenmediated gas fermentation reported until now to achieve the highest ethanol production yields [83]. Reported 
$\mathrm{CO}_{2}$-to- $\mathrm{CO}$ reduction efficiencies for $\mathrm{CO}_{2}$ electrolyzers being developed today are greater than $80 \%[84,85]$. Besides $\mathrm{CO}, \mathrm{CO}_{2}$ electrolyzers are being developed for the production of other $\mathrm{C} 1$ molecules, such as formate or methanol, which could also be used by microbial catalysts as electrons and carbon sources for the synthesis of multicarbon molecules including $\mathrm{C} 2$ and above biofuels [86-89].

\section{Photobioelectrochemical cells with microbes}

Multiple hybrid photosynthesis reactors developed in the recent years can be classified as photobioelectrochemical cells (PBECs). In these systems, light absorbers immersed in the electrolytes capture solar energy that will be used to split water at the (photo)anode and to generate reducing equivalents at the (photo)cathode (Fig. 2) [90]. Microbial or enzymatic catalysts will then reduce $\mathrm{CO}_{2}$ by acquiring reducing equivalents from the (photo)cathode. PBECs are derived from photoelectrochemical cells (PEC), which have been extensively investigated over the last 50 years [91]. These systems do not include a biocatalyst and have been mainly developed for the production of $\mathrm{H}_{2}$ to store energy from sunlight $[92,93]$. PEC and PBEC can include a photoanode, a photocathode, or both in a tandem configuration (Fig. 2a-c) [94]. Photoanodes are made of $n$-type semiconducting materials accumulating photoexcited holes that are used for water oxidation. The surface of the photoanode is often modified with oxygen evolution catalysts such as $\mathrm{IrO}_{2}$ to accelerate water splitting and improve photocurrent in the system. Electrons from oxidation reactions at the anode are then transferred via an electric circuit to the cathode. If a photocathode is included in the PEC or PBEC, it is made of a $p$-type semiconducting material where electrons coming from the (photo)anode are photoexcited to higher energy level. For $\mathrm{H}_{2}$ evolution, the photocathode is often modified with a hydrogen evolution catalyst such as platinum or earth-abundant and nonprecious metals [35, 95-97].

To our knowledge, the first functional microbial PBEC reported in the literature in 2015 was developed by Liu and coworkers at the University of California, Berkeley

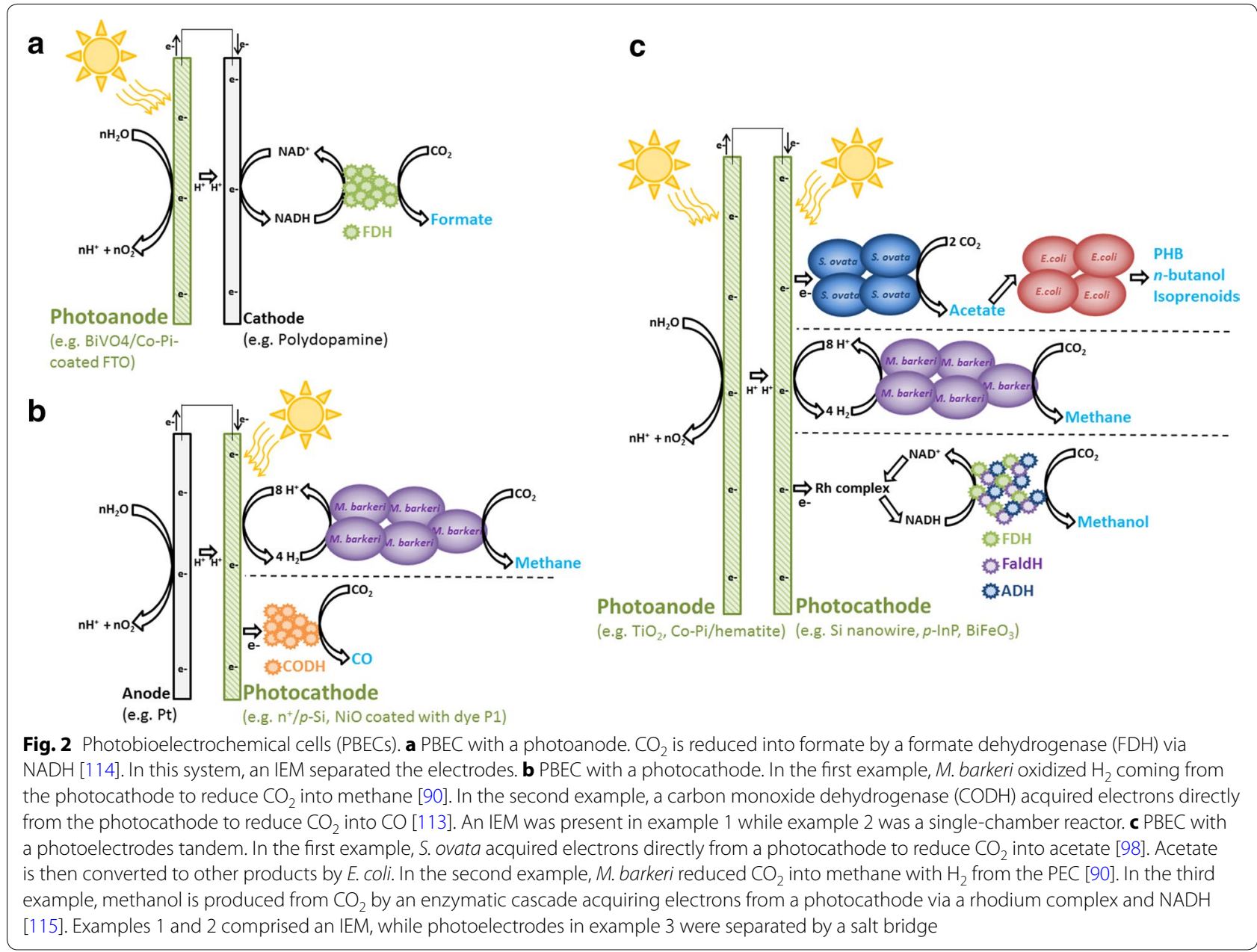


to produce $n$-butanol, $\mathrm{PHB}$, or isoprenoids from $\mathrm{CO}_{2}$ and solar energy (Table 1) [98]. This hybrid photosynthesis system consisted of light-absorbing $\mathrm{Si}$ nanowire photocathode and $\mathrm{TiO}_{2}$ photoanode separated by a cation-exchange membrane (Fig. 2c). Both the photocathode and the photoanode were exposed to light via quartz windows. The surface of the Si nanowire photocathode had three modifications: (1) a doped $\mathrm{n}^{+}$layer to improve photovoltage, (2) a $\mathrm{TiO}_{2}$ layer to increase stability at neutral $\mathrm{pH}$, and (3) a Ni and Pt layer to accelerate the transfer of reducing equivalents to the biocatalyst. The acetogen Sporomusa ovata was selected as the microbial catalyst because, as mentioned previously, it is particularly efficient at reducing $\mathrm{CO}_{2}$ into acetate with the cathode of an MES reactor as the sole electron source $[43,65,66,99]$. Interestingly, S. ovata is a strict anaerobe, but it was still able to synthesize acetate in this PBEC even though the $10 \% \mathrm{CO}_{2}$ feed also contained $21 \%$ $\mathrm{O}_{2}$. According to the authors, this occurrence is due to the conformation of the Si nanowire array photocathode, which harbors local anaerobic conditions. Under simulated sunlight, the PBEC was stable for more than $120 \mathrm{~h}$ with a photocurrent of $0.3 \mathrm{~mA} \mathrm{~cm}{ }^{-2}$. Acetate titer reached greater than $6 \mathrm{~g} / \mathrm{L}$, and the solar energy-toacetate efficiency of this proof-of-concept reactor was $0.38 \%$. Acetate produced by the PBEC was then used as feedstock in a downstream bioprocess by recombinant $E$. coli for the production of more valuable chemicals with longer carbon chains.

The same author group also developed two PBECs driven by the methanogen Methanosarcina barkeri for the production of methane from $\mathrm{CO}_{2}$ and solar energy (Table 1) [90]. In the first PBEC, only a portion of the electrical energy necessary for water splitting was derived from sunlight. The anode of platinum gauze was combined with a $n^{+} / p$-Si photocathode coated with a nickel-molybdene alloy evolving $\mathrm{H}_{2}$ to drive $M$. barkeri metabolism (Fig. 2b). This system produced $17.6 \mathrm{~mL} \mathrm{CH}_{4}$ over a period of 3 days and demonstrated that photoexciting electrons at a photocathode reduced the overpotential required for chemicals production using a bioelectrochemical reactor. The second methane-producing PBEC was powered exclusively by sunlight. It comprised a $n-\mathrm{TiO}_{2}$ nanowire/ fluorine-doped tin oxide (FTO) photoanode separated by an anion-exchange membrane from a $p$-InP photocathode coated with platinum for $\mathrm{H}_{2}$ evolution and colonized by M. barkeri (Fig. 2c). In this experiment, a full-light spectrum illuminated the photoanode before reaching the photocathode. Because of the sensitivity of methanogens to blue light, the PBEC reactor was also modified using a light filter inserted between both photoelectrodes. The sunlight-driven PBEC produced $1.75 \mathrm{~mL} \mathrm{CH}_{4}$ in 3 days.

PBEC using living cells as biocatalysts are still at an early stage of development as illustrated by the low productivity and solar energy-to-chemical conversion efficiency observed with these systems. Significant challenges must be overcome to reach the full potential of microbial PBEC including the development of biocompatible photocathodes that are optimal for both sunlight capture and electrons transfer to the biocatalyst. Based on the results in the literature until now, it could be argued that hybrid photosynthesis may be better served by a more compartmentalized system such as PV-driven MES or PV coupled with an electrolyzer and a gas bioreactor. With these approaches, components responsible for the conversions of solar energy-to-electrical and electrical-to-chemical energy can be optimized without consideration for maintaining conditions favorable to living cells that may limit performance and efficiency. Likewise, bioreactor components catalyzing the conversion of electrical or chemical energy into target molecules could be improved without consideration for sunlight capture. Still, PBEC like other PEC-based technologies is being pursued by the research community because, after considerable improvement, it may become more cost effective than PV-based technologies [100].

\section{Coupling inorganic photocatalysts with living cells}

Recently, two hybrid photosynthesis systems comprising photocatalyst nanoparticles driving the microbial reduction of $\mathrm{CO}_{2}$ into multicarbon compounds were developed by Sakimoto and coworkers (Table 1). In both systems, the microbial catalyst employed was the thermophilic Moorella thermoacetica, an acetogen mainly reducing $\mathrm{CO}_{2}$ into acetate also capable of acquiring electrons from a cathode $[53,101,102]$. The energy required to drive the autotrophic metabolism of $M$. thermoacetica came from light-harvesting $\mathrm{CdS}$ nanoparticles, which can oxidize the redox mediator cysteine. CdS nanoparticles were precipitated by $M$. thermoacetica and could be observed in clusters at the surface of microbial cells. The first system developed according to this strategy produced ca. $1.2 \mathrm{mM}$ acetic acid in 2.5 days under lowintensity-simulated sunlight. In the second system, a tandem "Z-scheme" architecture was adopted where cystine resulting from the oxidation of cysteine was reduced by a water-splitting catalyst composed of manganese(II) phthalocyanine (MnPC) cocatalyst attached to lightharvesting $\mathrm{TiO}_{2}$ nanoparticles (Fig. 3a). This system could produce ca. $0.6 \mathrm{mM}$ acetic acid within half a day of illumination. Compared with PV-based approaches 

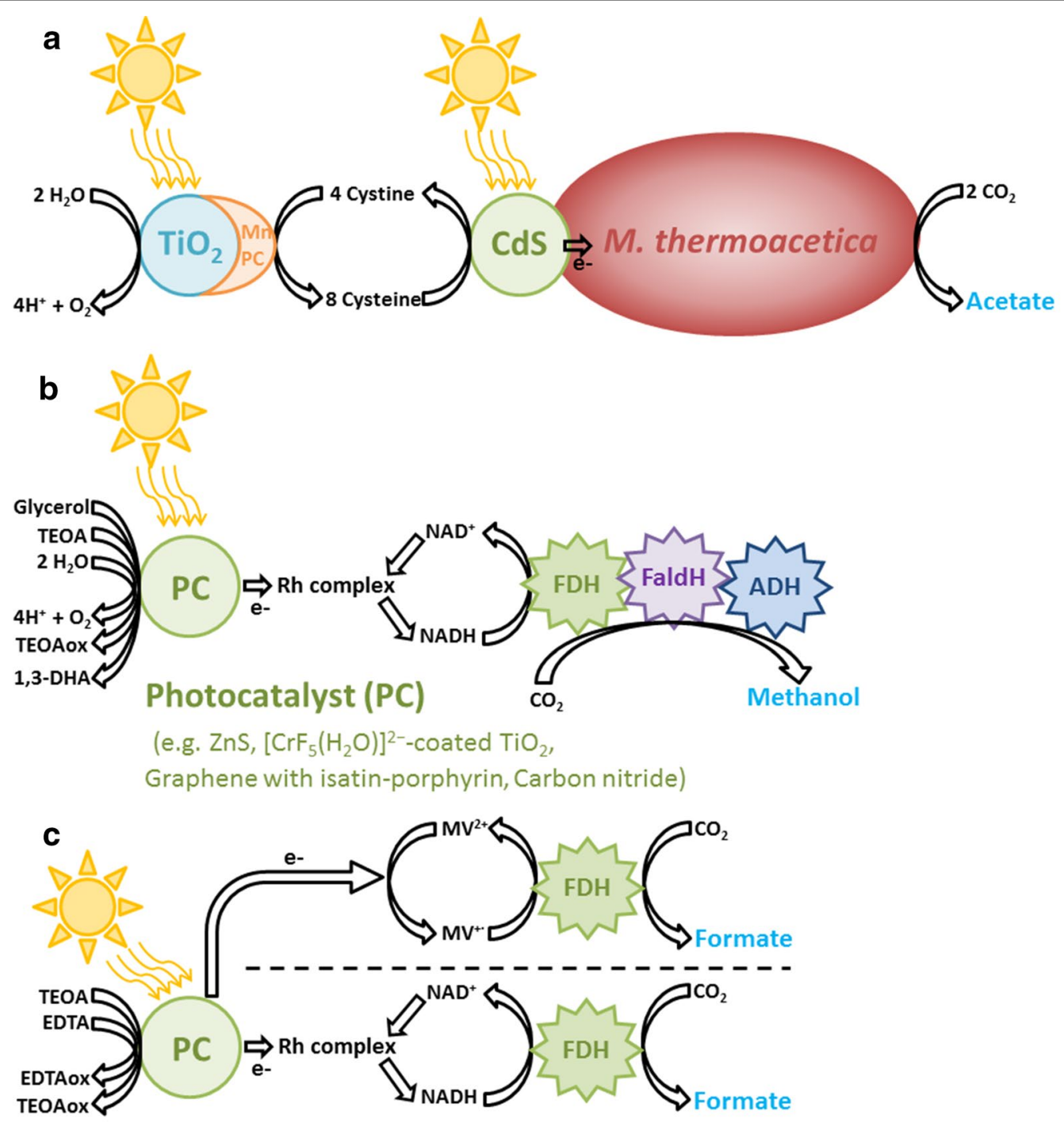

\section{Photocatalyst (PC)}

(e.g. Graphene modified with multi-

anthraquinone substituted porphyrin or BODIPY, Ru(bpy) ${ }_{3}{ }^{2+}$

Fig. 3 Hybrid photosynthesis using photocatalyst. a Photocatalyst-driven microbial $\mathrm{CO}_{2}$ reduction. In a tandem system, water is oxidized by a TiO 2 photocatalyst [102]. Electrons are transferred from $\mathrm{TiO}_{2}$ to cystine via a MnPC cocatalyst. The resulting cysteine is then oxidized by a CdS photocatalyst. M. thermoacetica reduced $\mathrm{CO}_{2}$ into acetate with electrons from $\mathrm{CdS}$. b Photocatalyst-driven enzymatic reduction of $\mathrm{CO}_{2}$ to methanol [116-119]. c Photocatalyst-driven enzymatic reduction of $\mathrm{CO}_{2}$ to formate. In the first example, electrons are transferred from the photocatalyst to the formate dehydrogenase $(\mathrm{FDH})$ via methylviologen [123]. In the second example, electrons are transferred from the photocatalyst to FDH via a rhodium complex and NADH $[120,121]$

and PBEC, coupling photocatalyst nanoparticles with microbial catalysts does not appear to be very productive. However, this technology is still in its infancy, and after significant improvement in terms of productivity and efficiency, it could become more cost effective than competing approaches since it requires only a single bioreactor without electrodes, PV cells, or electrolyzers.

\section{Hybrid photosynthesis with enzymes}

Besides living cells, hybrid photosynthesis systems for $\mathrm{CO}_{2}$ reduction could also be assembled with purified enzymes as biocatalyst (Table 2). This includes PV-based approaches, enzyme-driven PBEC, as well as strategies coupling inorganic photocatalysts with enzymes. Until now, enzyme-driven hybrid photosynthesis has only 
Table 2 Examples of hybrid photosynthesis system with enzymes as biocatalyst

\begin{tabular}{|c|c|c|c|c|}
\hline System & Light harvester & Enzyme & Comments & References \\
\hline PBEC & NiO photocathode with dye P1 & $\mathrm{CODH}$ & $\begin{array}{l}\text { Pt wire anode } \\
\text { Water splitting } \\
\text { Produces carbon monoxide }\end{array}$ & {$[113]$} \\
\hline PBEC & $\mathrm{BiVO}_{4}$ - and Co-Pi-coated FTO photoanode & $\mathrm{FDH}$ & $\begin{array}{l}\text { Polydopamine cathode } \\
\text { Water splitting } \\
\text { NADH as cofactor } \\
\text { Produces formate } \\
\text { Efficiency }^{\mathrm{a}}: 0.042 \%\end{array}$ & {$[114]$} \\
\hline PBEC & $\begin{array}{l}\mathrm{BiFeO}_{3} \text { photocathode } \\
\mathrm{Co}-\mathrm{Pi} / \text { hematite photoanode }\end{array}$ & FDH/FaldH/ADH & $\begin{array}{l}\text { Z-scheme } \\
\text { Water splitting } \\
\text { Rhodium complex used as redox mediator } \\
\text { Cofactor NADH } \\
220 \mu \mathrm{M} \mathrm{h}^{-1} \text { methanol }\end{array}$ & {$[115]$} \\
\hline PC & ZnS nanorods & $\mathrm{FDH} / \mathrm{FaldH} / \mathrm{ADH}$ & $\begin{array}{l}\text { Glycerol as } \mathrm{e}^{-} \text {donor } \\
\text { Cofactor NADH } \\
\text { Produces methanol }\end{array}$ & {$[116]$} \\
\hline PC & $\mathrm{TiO}_{2}$ nanoparticles coated with $\left[\mathrm{CrF}_{5}\left(\mathrm{H}_{2} \mathrm{O}\right)\right]^{2-}$ & FDH/FaldH/ADH & $\begin{array}{l}\text { Glycerol or water as } \mathrm{e}^{-} \text {donor } \\
\text { Rhodium complex used as redox mediator } \\
\text { Cofactor NADH } \\
\text { Produces methanol }\end{array}$ & {$[117]$} \\
\hline PC & $\begin{array}{l}\text { Graphene modified with isatin-porphyrin chromo- } \\
\text { phore }\end{array}$ & FDH/FaldH/ADH & $\begin{array}{l}\text { TEOA as } \mathrm{e}^{-} \text {donor } \\
\text { Rhodium complex used as redox mediator } \\
\text { Cofactor NADH } \\
7.47 \mu \mathrm{M} \mathrm{h}^{-1} \text { methanol }\end{array}$ & {$[118]$} \\
\hline PC & Carbon nitride array & FDH/FaldH/ADH & $\begin{array}{l}\text { TEOA as } \mathrm{e}^{-} \text {donor } \\
\text { Rhodium complex used as redox mediator } \\
\text { Cofactor NADH } \\
45 \mathrm{nM} \mathrm{h}^{-1} \text { methanol }\end{array}$ & {$[119]$} \\
\hline PC & $\begin{array}{l}\text { Graphene modified with multi-anthraquinone substi- } \\
\text { tuted porphyrin }\end{array}$ & $\mathrm{FDH}$ & $\begin{array}{l}\text { TEOA as } \mathrm{e}^{-} \text {donor } \\
\text { Rhodium complex used as redox mediator } \\
\text { Cofactor NADH } \\
55.5 \mu \mathrm{mol} \mathrm{h}^{-1} \text { formate }\end{array}$ & {$[120]$} \\
\hline PC & Graphene modified with the BODIPY molecule & $\mathrm{FDH}$ & $\begin{array}{l}\text { TEOA as } \mathrm{e}^{-} \text {donor } \\
\text { Rhodium complex used as redox mediator } \\
\text { Cofactor NADH } \\
72 \mu \mathrm{mol} \mathrm{h} \mathrm{h}^{-1} \text { formate }\end{array}$ & {$[121]$} \\
\hline PC & Photosensitizer Ru(bpy) ${ }_{3}^{2+}$ & $\mathrm{FDH}$ & $\begin{array}{l}\text { EDTA as } e^{-} \text {donor } \\
\text { Methylviologen used as redox mediator } \\
\text { Immobilization inside porous glass improved per- } \\
\quad \text { formance } \\
15 \mathrm{mM} \mathrm{h}^{-1} \text { formate } \\
\text { Efficiency: } 0.22 \%\end{array}$ & {$[123]$} \\
\hline
\end{tabular}

PBEC photobioelectrochemical cell, $C O D H$ carbon monoxide dehydrogenase, $F D H$ formate dehydrogenase, FaldH formaldehyde dehydrogenase, $A D H$ : alcohol dehydrogenase, $P C$ photocatalyst-driven system, TEOA triethanolamine, EDTA: ethylenediaminetetraacetic acid

a Efficiency refers to solar energy-to-product conversion efficiency

been developed for the reduction of $\mathrm{CO}_{2}$ into small $\mathrm{C} 1$ molecules including CO, formate, and methanol [103]. With the exception of methanol, these molecules cannot be used directly as fuel, but can serve as more reduced substrates than $\mathrm{CO}_{2}$ for downstream fuel-production processes. The narrow range of products is one of the disadvantages of enzyme-driven hybrid photosynthesis, which is also stymied by the cost and difficulties associated with enzyme purification and short lifetime [104, 105]. However, compared with living cell-driven hybrid photosynthesis, enzyme-based systems have also several advantages: (1) there is no requirement for complex microbial growth medium containing diverse nutrients augmenting cost, (2) products are more specific since living cells harbor multiple metabolic pathways leading to the synthesis of unwanted byproducts, and (3) energetic efficiency is not decreased by the need to generate and maintain biomass.

\section{Powering enzymatic electrosynthesis from $\mathrm{CO}_{2}$ with photovoltaics}

PVs could be used to power the enzymatic reduction of $\mathrm{CO}_{2}$ at the cathode of bioelectrochemical reactors. Enzymatic electrosynthesis (EE) is very similar to MES with 
the exception that the biocatalyst is an enzyme instead of a microbe (Fig. 1a) [106]. Until now, only formate and methanol have been produced from $\mathrm{CO}_{2}$ by EE. In the first report on EE, the tungsten-containing formate dehydrogenases of Syntrophobacter fumaroxidans appeared to accept electron directly from a cathode for the reversible reduction of $\mathrm{CO}_{2}$ into formate [107]. In systems developed later, the redox mediator, neutral red, transferred electrons from a carbonaceous cathode for the regeneration of NADH, which was then oxidized by a formate dehydrogenase [108-110]. Alternatively, a rhodium complex $\left[\mathrm{CpRh}(\mathrm{bpy})\left(\mathrm{H}_{2} \mathrm{O}\right)\right]^{2+}$ was employed to transfer electrons from a copper electrode to the cofactor NADH [111]. The neutral red-based EE system developed by Addo and coworkers included a formaldehyde dehydrogenase and an alcohol dehydrogenase with the formate dehydrogenase to establish an enzymatic cascade enabling the production of methanol from $\mathrm{CO}_{2}$ [109]. This system also comprised a carbonic anhydrase for the conversion of dissolved $\mathrm{CO}_{2}$ into bicarbonate, which accelerated the EE reaction.

Most formate-producing EE processes described in the literature had a coulombic efficiency below 13\% with the exception of a system developed by Zhang and coworkers. They immobilized the formate dehydrogenase of Candida boidinii with Nafion micelles at the surface of a cathode coated with neutral red and poised at $-0.8 \mathrm{~V}$ (vs. SHE). Nafion micelles increased the lifetime of the fragile formate dehydrogenase and protected its enzyme activity. The reported coulombic efficiency of this system was $77.08 \%$ with a production rate of $64.71 \mathrm{mg} \mathrm{L}^{-1} \mathrm{~h}^{-1}$ over a period of $2 \mathrm{~h}$ [112]. Within this range of coulombic efficiency, powering EE with PV could result in a hybrid photosynthesis system with a significant solar energy-toformate conversion efficiency.

\section{Photobioelectrochemical cells with enzymes}

Examples of PBEC driven by enzyme include a system where the carbon monoxide dehydrogenase I of the thermophilic and chemolithotrophic bacterium Carboxydothermus hydrogenoformans can reduce $\mathrm{CO}_{2}$ into $\mathrm{CO}$ with electrons coming from a photocathode (Fig. 2b, Table 2) [113]. This electrode made of a $p$-type semiconductor $\mathrm{NiO}$ was photosensitized using the organic dye P1 responsive to visible light. In this PBEC, photoexcited electrons from the photocathode were first transferred to the FeS clusters of the carbon monoxide dehydrogenase I before reaching the Ni4Fe- $4 \mathrm{~S}$ active site of the enzyme. The counter-electrode, oxidizing water in this system, was made of platinum wire. In a second example, Lee and coworkers designed a PBEC for the reduction of $\mathrm{CO}_{2}$ into formate, coupling a photoanode splitting water by means of a cathode made of polydopamine coated with the formate dehydrogenase of C. boidini and its cofactor NADH (Fig. 2a) [114]. Polydopamine was chosen as cathode material because it is biocompatible, and it has a good charge-transfer capacity. Electrons from the cathode were transferred to the active site of the formate dehydrogenase via the reduction of $\mathrm{NAD}^{+}$into NADH. The photoanode was a FTO electrode coated with the visible-light-absorber $\mathrm{BiVO}_{4}$ and with the water oxidation catalyst $\mathrm{Co}-\mathrm{Pi}$. This system had a solar energy-toformate conversion efficiency of $0.042 \%$ and was stable for at least $24 \mathrm{~h}$.

Recently, Kuk and coworkers designed an enzymedriven PBEC for the reduction of $\mathrm{CO}_{2}$ to methanol with a visible light-absorbing photocathode and photoanode tandem (Fig. 2c; Table 2) [115]. The photocathode was made of a $p$-type perovskite semiconductor $\mathrm{BiFeO}_{3}$, and the photoanode comprised hematite and Co-Pi. Photoexcited electrons from the photocathode regenerated the cofactor NADH via a rhodium complex as redox mediator. Water was oxidized at the photoanode by the Co-Pi catalyst. With this system, a high visible lightdriven methanol conversion output of $220 \mu \mathrm{M} \mathrm{h}^{-1}$ was observed, but only when applying an electrical bias of $0.8 \mathrm{~V}$.

\section{Coupling inorganic photocatalysts with enzymes}

The three enzymes cascade used to produce methanol have also been coupled with different photocatalytic nanoparticles driving the photochemical regeneration of NADH (Table 2; Fig. 3b). For instance, Dibenedetto and coworkers proposed a system coupling methanol production with $\mathrm{NAD}^{+}$reduction by a $\mathrm{ZnS}$ photocatalyst using glycerol as electron donor and illuminated by light at the border of the visible and UV spectra [116]. The same group later assembled a system relying on a visiblelight-absorbing photocatalyst made of $\mathrm{TiO}_{2}$ coated with the photosensitizer $\left[\mathrm{CrF}_{5}\left(\mathrm{H}_{2} \mathrm{O}\right)\right]^{2-}$ for the regeneration of NADH followed by methanol production [117]. With this system, water could be used as the electron donor for $\mathrm{NAD}^{+}$reduction, but the photocatalyst was more efficient with glycerol. Furthermore, adding a rhodium complex to serve as redox mediator significantly improved $\mathrm{NADH}$ regeneration. Other visible-light-harvesting photocatalysts developed for NADH regeneration coupled with the enzymatic production of methanol include graphene modified with isatin-porphyrin chromophore and carbon nitride semiconductor array combined with a rhodium complex $[118,119]$. These two systems used triethanolamine (TEOA) as electron donor for the photoregeneration of NADH. The graphene modified with isatin-porphyrin photocatalyst was the most productive system with $11.21 \mu \mathrm{M}$ methanol being produced from $\mathrm{CO}_{2}$ within 90 min. 
Photocatalytic particles have been used likewise to regenerate NADH for the enzymatic production of formate (Fig. 3c; Table 2). For this purpose, Yadav and coworkers developed visible-light-absorbing photocatalysts coupling the oxidation of TEOA with NADH regeneration via a rhodium complex as redox mediator. These photocatalysts were made of graphene modified with either multianthraquinone-substituted porphyrin or the lightharvesting BODIPY compound [120, 121]. Within $2 \mathrm{~h}$ of operation, the two formate dehydrogenase-coupled photocatalysts could produce 111 and $144 \mu \mathrm{mol}$ of formate, respectively. Graphene was used in the fabrication of photocatalyst composites such as the three examples described here, because it has a high charge-transport efficiency and an excellent specific surface area, which are both beneficial for photocatalytic and photovoltaic systems [122].

Recently, Noji and coworkers developed a light-induced formate production system where the redox mediator methylviologen transferred electrons from the photosensitizer $\mathrm{Ru}(\mathrm{bpy})_{3}^{2+}$ to a formate dehydrogenase reducing $\mathrm{CO}_{2}$ (Fig. 3c) [123]. In this case, the photosensitizer oxidized EDTA for the reduction of methylviologen. The formate production rate and the solar energy-to-formate conversion efficiency of this system were $0.18 \mathrm{mM} \mathrm{h}^{-1}$ and $0.016 \%$, respectively. Interestingly, when the photosensitizer, methylviologen, and the formate dehydrogenase were immobilized inside the nanopore of porous glass plates, the three components became denser, the production rate was increased to $15 \mathrm{mM} \mathrm{h}^{-1}$, and the efficiency was also significantly improved to $0.22 \%$. Beside low productivity and efficiency, the usage of electron donors other than water for the biophotocatalytic production of methanol or formate via enzymes is one of the major hurdles between this technology and practical applications, especially since compounds such as EDTA and TEOA need to be regenerated after oxidation.

\section{Conclusions}

Hybrid photosynthesis is a novel technology still at an early stage of development, regardless of whether it can be combined with more mature technologies like PV cell and electrolyzer. In our opinion, it is premature to make economic comparison between the various types of hybrid photosynthesis systems described here since multiple technical parameters could be dramatically improved in the near future. Increasing the efficiency and productivity of hybrid photosynthesis systems need to be done in part via the optimization of the light-harvesting inorganic apparatus and of the biocatalyst. To reach this objective, cheaper and better semiconductor materials must be developed for the fabrication of biocompatible photocatalysts or photoelectrodes, and novel biocatalysts accelerating the light-driven reduction of
$\mathrm{CO}_{2}$ into specific products must be engineered through well-thought synthetic biology approaches. In addition, to reach the practical voltage required for water oxidation and microbial $\mathrm{CO}_{2}$ reduction, it may be advantageous to design novel reactor architecture combining several of the hybrid photosynthesis strategies described here. For instance, coupling the photocathode of a PBEC and its associated biocatalyst with a PV cell could lead to higher energetic efficiency [32, 35]. Another promising avenue of research for the transformation of solar energy into multicarbon biofuels that should be investigated is the conversion of solar heat into reducing equivalents, which could then be used to drive the biological reduction of $\mathrm{CO}_{2}$ [124]. Since a large fraction of solar energy is converted into heat, a hybrid photosynthesis system harvesting both sunlight and solar heat could lead to a significant increase in productivity and in solar energyto-biofuels conversion efficiency.

Development of robust, safe, cost-effective, productive, and efficient hybrid photosynthesis systems could be a major technological breakthrough. However, many important challenges other than improving efficiency and performance remained before possible scaling up. This includes limitation associated with the usage of atmospheric $\mathrm{CO}_{2}$ as carbon source [8]. $\mathrm{CO}_{2}$ is present in low concentration in the atmosphere and would probably have to be enriched, which could significantly increase cost associated with hybrid photosynthesis. A more reasonable solution would be to use $\mathrm{CO}_{2}$-rich flue gas as feedstock, which can be obtained directly from industrial emitters such as ceramic, glass, steel, and power plant, or from anaerobic digestion plant. A second issue that could prevent hybrid photosynthesis from becoming economically feasible is product separation and extraction from the electrolyte/growth medium, which can account for the major fraction of the cost associated with microbial bioproduction plants [125]. A potential cheaper solution that has been implemented successfully in bioelectrochemical reactors for carboxylic acids would be to separate products in PBEC or in PVbased reactor using integrated membrane electrolysis [126, 127]. Based on these observations, it is clear that research on hybrid photosynthesis has many questions left unanswered and obstacles to overcome. Nevertheless, this field of activity is under rapid development and is showing exciting promises for the future of bioenergy.

\footnotetext{
Abbreviations

ADH: alcohol dehydrogenase; CODH: carbon monoxide dehydrogenase; EDTA: ethylenediaminetetraacetic acid; EE: enzymatic electrosynthesis; FaldH: formaldehyde dehydrogenase; FDH: formate dehydrogenase; FTO: fluorine-doped tin oxide; IEA: International Energy Agency; IEM: ion-exchange membrane; MES: microbial electrosynthesis; MnPC: manganese(II) phthalocyanine; NR: neutral red; PBEC: photobioelectrochemical cell; PEC: photoelectrochemical cell; PHB: polyhydroxybutyrate; PEM: polymer electrolyte membrane; PV: photovoltaic; SHE: standard hydrogen electrode; TEOA: triethanolamine.
} 


\section{Authors' contributions}

TZ and PLT developed, wrote, and revised the manuscript. Both authors read and approved the final manuscript.

\section{Acknowledgements \\ Not applicable.}

\section{Competing interests}

The authors declare that they have no competing interests.

\section{Consent for publication}

Not applicable.

Ethical approval and consent to participate

Not applicable.

\section{Funding}

PLT acknowledges the financial support by the Wuhan University of Technology. TZ acknowledges the financial support by the Chinese Thousand Talents Plan Program.

\section{Publisher's Note}

Springer Nature remains neutral with regard to jurisdictional claims in published maps and institutional affiliations.

Received: 22 August 2017 Accepted: 24 October 2017

Published online: 30 October 2017

\section{References}

1. Fossil fuel energy consumption (\% of total)|Data. http://data.worldbank. org/indicator/EG.USE.COMM.FO.ZS. Accessed 15 Aug 2017.

2. Fossil fuels — chemistry encyclopedia — water, gas, coal, coke, petroleum, natural gas. http://www.chemistryexplained.com/Fe-Ge/FossilFuels.html. Accessed 15 Aug 2017.

3. US EPA O. Global Greenhouse Gas Emissions Data. US EPA. 2016. https:// www.epa.gov/ghgemissions/global-greenhouse-gas-emissions-data. Accessed 13 Oct 2017.

4. Why does $\mathrm{CO}_{2}$ get most of the attention when there are so many other heat-trapping gases?|Union of Concerned Scientists. http://www. ucsusa.org/global_warming/science_and_impacts/science/CO2-andglobal-warming-faq.html\#.WSRKXNwiGpo. Accessed 15 Aug 2017.

5. Solterra. http://www.solterrasolarcells.com/sunsrays.php. Accessed 15 Aug 2017.

6. Energy Technology Perspectives. http://www.iea.org/etp/. Accessed 15 Aug 2017.

7. Blankenship RE, Tiede DM, Barber J, Brudvig GW, Fleming G, Ghirardi $M$, et al. Comparing photosynthetic and photovoltaic efficiencies and recognizing the potential for improvement. Science. 2011;332:805-9.

8. Lewis NS. Research opportunities to advance solar energy utilization. Science. 2016;351:aad1920.

9. Olson JM. Photosynthesis in the archean era. Photosynth Res. 2006;88:109-17.

10. Mallick N, Bagchi SK, Koley S, Singh AK. Progress and challenges in microalgal biodiesel production. Front. Microbiol. 2016;7:1019.

11. Durrett TP, Benning C, Ohlrogge J. Plant triacylglycerols as feedstocks for the production of biofuels. Plant J Cell Mol Biol. 2008;54:593-607.

12. Du Z-Y, Benning C. Triacylglycerol accumulation in photosynthetic cells in plants and algae. Subcell Biochem. 2016;86:179-205.

13. Oliver NJ, Rabinovitch-Deere CA, Carroll AL, Nozzi NE, Case AE, Atsumi S. Cyanobacterial metabolic engineering for biofuel and chemical production. Curr Opin Chem Biol. 2016;35:43-50.

14. Nybo SE, Khan NE, Woolston BM, Curtis WR. Metabolic engineering in chemolithoautotrophic hosts for the production of fuels and chemicals. Metab Eng. 2015:30:105-20.

15. Kwak S, Jin Y-S. Production of fuels and chemicals from xylose by engineered Saccharomyces cerevisiae: a review and perspective. Microb Cell Fact. 2017;16:82.
16. Wheeldon I, Christopher P, Blanch H. Integration of heterogeneous and biochemical catalysis for production of fuels and chemicals from biomass. Curr Opin Biotechnol. 2017;45:127-35.

17. Feltus FA, Vandenbrink JP. Bioenergy grass feedstock: current options and prospects for trait improvement using emerging genetic, genomic, and systems biology toolkits. Biotechnol Biofuels. 2012;5:80.

18. Weng J-K, Li X, Bonawitz ND, Chapple C. Emerging strategies of lignin engineering and degradation for cellulosic biofuel production. Curr Opin Biotechnol. 2008;19:166-72.

19. Kawaguchi H, Ogino C, Kondo A. Microbial conversion of biomass into bio-based polymers. Bioresour Technol. 2017;245:1664-73.

20. Claassens NJ, Sousa DZ, dos Santos VAPM, de Vos WM, van der Oost J. Harnessing the power of microbial autotrophy. Nat Rev Microbiol. 2016;14:692-706

21. Conrado RJ, Haynes CA, Haendler BE, Toone EJ. Electrofuels: a new paradigm for renewable fuels. Adv Biofuels Bioprod. New York: Springer; 2013. https://link.springer.com/chapter/10.1007/978-1-4614-3348-4_38. Accessed 15 Aug 2017.

22. Wijffels RH, Barbosa MJ. An outlook on microalgal biofuels. Science. 2010;329:796-9.

23. Leal MRLV, Walter AS, Seabra JEA. Sugarcane as an energy source. Biomass Convers Biorefin. 2013:3:17-26.

24. Dann M, Leister D. Enhancing (crop) plant photosynthesis by introducing novel genetic diversity. Philos Trans R Soc Lond B Biol Sci. 2017;372:1730.

25. Kromdijk J, Głowacka K, Leonelli L, Gabilly ST, Iwai M, Niyogi KK, et al. Improving photosynthesis and crop productivity by accelerating recovery from photoprotection. Science. 2016;354:857-61.

26. Lin MT, Occhialini A, Andralojc PJ, Parry MAJ, Hanson MR. A faster Rubisco with potential to increase photosynthesis in crops. Nature. 2014;513:547-50.

27. Gomaa MA, Al-Haj L, Abed RMM. Metabolic engineering of Cyanobacteria and microalgae for enhanced production of biofuels and high-value products. J Appl Microbiol. 2016;121:919-31.

28. Meyer MT, McCormick AJ, Griffiths $\mathrm{H}$. Will an algal $\mathrm{CO}_{2}$-concentrating mechanism work in higher plants? Curr Opin Plant Biol. 2016;31:181-8.

29. Lovley DR, Nevin KP. Electrobiocommodities: powering microbial production of fuels and commodity chemicals from carbon dioxide with electricity. Curr Opin Biotechnol. 2013;24:385-90.

30. Zhang T. More efficient together. Science. 2015;350:738-9.

31. Green MA, Emery K, Hishikawa Y, Warta W, Dunlop ED. Solar cell efficiency tables (version 46). Prog Photovolt Res Appl. 2015;23:805-12.

32. Ager JW, Shaner MR, Walczak KA, Sharp ID, Ardo S. Experimental demonstrations of spontaneous, solar-driven photoelectrochemical water splitting. Energy Environ Sci. 2015;8:2811-24.

33. Licht S, Wang B, Mukerji S, Soga T, Umeno M, Tributsch H. Efficient solar water splitting, exemplified by $\mathrm{RuO}_{2}$-catalyzed AIGaAs/Si photoelectrolysis. J Phys Chem B. 2000;104:8920-4.

34. Khaselev O, Bansal A, Turner JA. High-efficiency integrated multijunction photovoltaic/electrolysis systems for hydrogen production. Int J Hydrog Energy. 2001;26:127-32.

35. Khaselev O, Turner JA. A monolithic photovoltaic-photoelectrochemical device for hydrogen production via water splitting. Science. 1998;280:425-7.

36. Luo J, Im J-H, Mayer MT, Schreier M, Nazeeruddin MK, Park N-G, et al. Water photolysis at $12.3 \%$ efficiency via perovskite photovoltaics and earth-abundant catalysts. Science. 2014;345:1593-6.

37. Peharz G, Dimroth F, Wittstadt U. Solar hydrogen production by water splitting with a conversion efficiency of 18\%. Int J Hydrog Energy. 2007:32:3248-52.

38. Young JL, Steiner MA, Döscher H, France RM, Turner JA, Deutsch TG. Direct solar-to-hydrogen conversion via inverted metamorphic multijunction semiconductor architectures. Nat Energy. 2017;2:17028.

39. Sakimoto KK, Kornienko N, Yang P. Cyborgian material design for solar fuel production: the emerging photosynthetic biohybrid systems. Acc Chem Res. 2017:50:476-81.

40. Zhou H, Yan R, Zhang D, Fan T. Challenges and perspectives in designing artificial photosynthetic systems. Chemistry. 2016;22:9870-85.

41. Tremblay P-L, Angenent LT, Zhang T. Extracellular electron uptake: among autotrophs and mediated by surfaces. Trends Biotechnol. 2017;35:360-71. 
42. Woo HM. Solar-to-chemical and solar-to-fuel production from $\mathrm{CO}_{2}$ by metabolically engineered microorganisms. Curr Opin Biotechnol. 2017;45:1-7.

43. Nevin KP, Woodard TL, Franks AE, Summers ZM, Lovley DR. Microbial electrosynthesis: feeding microbes electricity to convert carbon dioxide and water to multicarbon extracellular organic compounds. MBio. 2010;1:e00103.

44. Torella JP, Gagliardi CJ, Chen JS, Bediako DK, Colón B, Way JC, et al. Efficient solar-to-fuels production from a hybrid microbial-water-splitting catalyst system. Proc Natl Acad Sci. 2015;112:2337-42

45. Tremblay P-L, Zhang T. Electrifying microbes for the production of chemicals. Front Microbiol. 2015;6:201.

46. Rabaey K, Rozendal RA. Microbial electrosynthesis-revisiting the electrical route for microbial production. Nat Rev Microbiol. 2010;8:706-16.

47. Gong Y, Ebrahim A, Feist AM, Embree M, Zhang T, Lovley D, et al. Sulfide-driven microbial electrosynthesis. Environ Sci Technol. 2013;47:568-73.

48. Zhang T, Bain TS, Barlett MA, Dar SA, Snoeyenbos-West OL, Nevin KP, et al. Sulfur oxidation to sulfate coupled with electron transfer to electrodes by Desulfuromonas strain TZ1. Microbiology. 2014;160:123-9.

49. Jiang Y, Su M, Li D. Removal of sulfide and production of methane from carbon dioxide in microbial fuel cells-microbial electrolysis cell (MFCsMEC) coupled system. Appl Biochem Biotechnol. 2014;172:2720-31.

50. Zeppilli M, Villano M, Aulenta F, Lampis S, Vallini G, Majone M. Effect of the anode feeding composition on the performance of a continuousflow methane-producing microbial electrolysis cell. Environ Sci Pollut Res Int 2015:22:7349-60.

51. Siegert M, Li X-F, Yates MD, Logan BE. The presence of hydrogenotrophic methanogens in the inoculum improves methane gas production in microbial electrolysis cells. Front Microbiol. 2014;5:778.

52. Ganigué R, Puig S, Batlle-Vilanova P, Balaguer MD, Colprim J. Microbia electrosynthesis of butyrate from carbon dioxide. Chem Commun. 2015:51:3235-8.

53. Nevin KP, Hensley SA, Franks AE, Summers ZM, Ou J, Woodard TL, et al. Electrosynthesis of organic compounds from carbon dioxide is catalyzed by a diversity of acetogenic microorganisms. Appl Environ Microbiol. 2011;77:2882-6.

54. Marshall CW, Ross DE, Fichot EB, Norman RS, May HD. Long-term operation of microbial electrosynthesis systems improves acetate production by autotrophic microbiomes. Environ Sci Technol. 2013:47:6023-9.

55. Li H, Opgenorth PH, Wernick DG, Rogers S, Wu T-Y, Higashide W, et al. Integrated electromicrobial conversion of $\mathrm{CO}_{2}$ to higher alcohols. Science. 2012;335:1596.

56. Lehtinen T, Efimova E, Tremblay P-L, Santala S, Zhang T, Santala V. Production of long chain alkyl esters from carbon dioxide and electricity by a two-stage bacterial process. Bioresour Technol. 2017:243:30-6.

57. Cheng S, Xing D, Call DF, Logan BE. Direct biological conversion of electrical current into methane by electromethanogenesis. Environ Sci Technol. 2009:43:3953-8.

58. Marshall CW, Ross DE, Fichot EB, Norman RS, May HD. Electrosynthesis of commodity chemicals by an autotrophic microbial community. Appl Environ Microbiol. 2012;78:8412-20.

59. Bajracharya S, ter Heijne A, Dominguez Benetton X, Vanbroekhoven K, Buisman CJN, Strik DPBTB, et al. Carbon dioxide reduction by mixed and pure cultures in microbial electrosynthesis using an assembly of graphite felt and stainless steel as a cathode. Bioresour Technol. 2015:195:14-24

60. Bajracharya S, Vanbroekhoven K, Buisman CJN, Pant D, Strik DPBTB. Application of gas diffusion biocathode in microbial electrosynthesis from carbon dioxide. Environ Sci Pollut Res Int. 2016:23:22292-308.

61. Bajracharya S, Yuliasni R, Vanbroekhoven K, Buisman CJN, Strik DPBTB, Pant D. Long-term operation of microbial electrosynthesis cell reducing $\mathrm{CO}_{2}$ to multi-carbon chemicals with a mixed culture avoiding methanogenesis. Bioelectrochemistry. 2017;113:26-34.

62. Ammam F, Tremblay P-L, Lizak DM, Zhang T. Effect of tungstate on acetate and ethanol production by the electrosynthetic bacterium Sporomusa ovata. Biotechnol Biofuels. 2016;9:163.

63. Aryal N, Halder A, Tremblay P-L, Chi Q, Zhang T. Enhanced microbial electrosynthesis with three-dimensional graphene functionalized cathodes fabricated via solvothermal synthesis. Electrochim Acta. 2016:217:117-22
64. Aryal N, Tremblay P-L, Lizak DM, Zhang T. Performance of different Sporomusa species for the microbial electrosynthesis of acetate from carbon dioxide. Bioresour Technol. 2017;233:184-90.

65. Tremblay P-L, Höglund D, Koza A, Bonde I, Zhang T. Adaptation of the autotrophic acetogen Sporomusa ovata to methanol accelerates the conversion of $\mathrm{CO}_{2}$ to organic products. Sci Rep. 2015;5:16168.

66. Chen L, Tremblay P-L, Mohanty S, Xu K, Zhang T. Electrosynthesis of acetate from $\mathrm{CO}_{2}$ by a highly structured biofilm assembled with reduced graphene oxide-tetraethylene pentamine. J Mater Chem A. 2016;4:8395-401.

67. Yu L, Yuan Y, Tang J, Zhou S. Thermophilic Moorella thermoautotrophicaimmobilized cathode enhanced microbial electrosynthesis of acetate and formate from $\mathrm{CO}_{2}$. Bioelectrochemistry. 2017;117:23-8.

68. Summers ZM, Gralnick JA, Bond DR. Cultivation of an obligate $\mathrm{Fe}(\mathrm{II})$-oxidizing lithoautotrophic bacterium using electrodes. MBio. 2013:4:e00420-12

69. Khunjar WO, Sahin A, West AC, Chandran K, Banta S. Biomass produCtion from electricity using ammonia as an electron carrier in a reverse microbial fuel cell. PLoS ONE. 2012;7:e44846.

70. Bose A, Gardel EJ, Vidoudez C, Parra EA, Girguis PR. Electron uptake by iron-oxidizing phototrophic bacteria. Nat Commun. 2014;5:3391.

71. Carbajosa S, Malki M, Caillard R, Lopez MF, Palomares FJ, Martín-Gago $J A$, et al. Electrochemical growth of Acidithiobacillus ferrooxidans on a graphite electrode for obtaining a biocathode for direct electrocatalytic reduction of oxygen. Biosens Bioelectron. 2010;26:877-80.

72. Doud DFR, Angenent LT. Toward electrosynthesis with uncoupled extracellular electron uptake and metabolic growth: enhancing current uptake with Rhodopseudomonas palustris. Environ Sci Technol Lett. 2014;1:351-5.

73. Zheng C, Kammen DM. An innovation-focused roadmap for a sustainable global photovoltaic industry. Energy Policy. 2014;67:159-69.

74. Dimroth F, Tibbits TND, Niemeyer M, Predan F, Beutel P, Karcher C, et al. Four-junction wafer-bonded concentrator solar cells. IEEE J Photovolt. 2016;6:343-9

75. Jhong $\mathrm{H}-\mathrm{R}$, Ma S, Kenis PJ. Electrochemical conversion of $\mathrm{CO}_{2}$ to useful chemicals: current status, remaining challenges, and future opportunities. Curr Opin Chem Eng. 2013;2:191-9.

76. Harnisch F, Rosa LFM, Kracke F, Virdis B, Krömer JO. Electrifying white biotechnology: engineering and economic potential of electricitydriven bio-production. Chemsuschem. 2015:8:758-66.

77. Liu C, Colón BC, Ziesack M, Silver PA, Nocera DG. Water splitting-biosynthetic system with $\mathrm{CO}_{2}$ reduction efficiencies exceeding photosynthesis. Science. 2016;352:1210-3.

78. Ishizaki A, Tanaka K, Taga N. Microbial production of poly-D-3-hydroxybutyrate from $\mathrm{CO}_{2}$. Appl Microbiol Biotechnol. 2001;57:6-12.

79. Slater S, Houmiel KL, Tran M, Mitsky TA, Taylor NB, Padgette SR, et al. Multiple beta-ketothiolases mediate poly(beta-hydroxyalkanoate) copolymer synthesis in Ralstonia eutropha. J Bacteriol. 1998;180:1979-87.

80. Deutzmann JS, Sahin M, Spormann AM. Extracellular enzymes facilitate electron uptake in biocorrosion and bioelectrosynthesis. Mbio. 2015;6:e00496-515.

81. Jourdin L, Lu Y, Flexer V, Keller J, Freguia S. Biologically induced hydrogen production drives high rate/high efficiency microbial electrosynthesis of acetate from carbon dioxide. ChemElectroChem. 2016;3:581-91.

82. Liew F, Martin ME, Tappel RC, Heijstra BD, Mihalcea C, Köpke M. Gas fermentation-a flexible platform for commercial scale production of low-carbon-fuels and chemicals from waste and renewable feedstocks. Front Microbiol. 2016:7:694.

83. Gaddy J, Arora D, Ko C-W, Phillips J, Basu R, Wikstrom C, et al. Methods for increasing the production of ethanol from microbial fermentation. 2002. https://patentscope.wipo.int/search/en/detail. jsf?docld=WO2002008438. Accessed 15 Aug 2017

84. Lin S, Diercks CS, Zhang Y-B, Kornienko N, Nichols EM, Zhao Y, et al. Covalent organic frameworks comprising cobalt porphyrins for catalytic $\mathrm{CO}_{2}$ reduction in water. Science. 2015;349:1208-13.

85. $\mathrm{CO}_{2}$ electrolyzer nears commercialization|Chemical \& Engineering News. http://cen.acs.org/articles/93/i13/CO2-Electrolyzer-Nears-Commercialization.html. Accessed 15 Aug 2017. 
86. Crable BR, Plugge CM, McInerney MJ, Stams AJM. Formate formation and formate conversion in biological fuels production. Enzyme Res. 2011:2011:532536.

87. Qiao J, Liu Y, Hong F, Zhang J. A review of catalysts for the electroreduction of carbon dioxide to produce low-carbon fuels. Chem Soc Rev. 2013;43:631-75

88. Appel AM, Bercaw JE, Bocarsly AB, Dobbek H, DuBois DL, Dupuis M et al. Frontiers, opportunities, and challenges in biochemical and chemical catalysis of $\mathrm{CO}_{2}$ fixation. Chem Rev. 2013;113:6621-58.

89. Schrader J, Schilling M, Holtmann D, Sell D, Filho MV, Marx A, et al. Methanol-based industrial biotechnology: current status and future perspectives of methylotrophic bacteria. Trends Biotechnol. 2009;27:107-15

90. Nichols EM, Gallagher JJ, Liu C, Su Y, Resasco J, Yu Y, et al. Hybrid bioinorganic approach to solar-to-chemical conversion. Proc Natl Acad Sci. 2015:112:11461-6.

91. Fujishima A, Honda K. Electrochemical photolysis of water at a semiconductor electrode. Nature. 1972;238:37-8.

92. Li Z, Luo W, Zhang M, Feng J, Zou Z. Photoelectrochemical cells for solar hydrogen production: current state of promising photoelectrodes, methods to improve their properties, and outlook. Energy Environ Sci. 2013:6:347-70.

93. Li J, Wu N. Semiconductor-based photocatalysts and photoelectrochemical cells for solar fuel generation: a review. Catal Sci Technol. 2015;5:1360-84

94. Hisatomi T, Kubota J, Domen K. Recent advances in semiconductors for photocatalytic and photoelectrochemical water splitting. Chem Soc Rev. 2014;43:7520-35.

95. Morales-Guio CG, Liardet L, Mayer MT, Tilley SD, Grätzel M, Hu X. Photoelectrochemical hydrogen production in alkaline Solutions using $\mathrm{Cu}_{2} \mathrm{O}$ coated with earth-abundant hydrogen evolution catalysts. Angew Chem Int Ed. 2015;54:664-7.

96. Warren EL, McKone JR, Atwater HA, Gray HB, Lewis NS. Hydrogenevolution characteristics of $\mathrm{Ni}-\mathrm{Mo}$-coated, radial junction, $n^{+} p$-silicon microwire array photocathodes. Energy Environ Sci. 2012;5:9653-61.

97. Hou Y, Abrams BL, Vesborg PCK, Björketun ME, Herbst K, Bech L, et al. Bioinspired molecular co-catalysts bonded to a silicon photocathode for solar hydrogen evolution. Nat Mater. 2011;10:434-8.

98. Liu C, Gallagher JJ, Sakimoto KK, Nichols EM, Chang CJ, Chang MCY, et al. Nanowire-bacteria hybrids for unassisted solar carbon dioxide fixation to value-added chemicals. Nano Lett. 2015;15:3634-9.

99. Zhang T, Nie H, Bain TS, Lu H, Cui M, Snoeyenbos-West OL, et al. Improved cathode materials for microbial electrosynthesis. Energy Environ Sci. 2013;6:217-24.

100. Rothschild A, Dotan H. Beating the efficiency of photovoltaics-powered electrolysis with tandem cell photoelectrolysis. ACS Energy Lett. 2017;2:45-51

101. Sakimoto KK, Wong AB, Yang P. Self-photosensitization of nonphotosynthetic bacteria for solar-to-chemical production. Science. 2016;351:74-7.

102. Sakimoto KK, Zhang SJ, Yang P. Cysteine-cystine photoregeneration for oxygenic photosynthesis of acetic acid from $\mathrm{CO}_{2}$ by a tandem inorganic-biological hybrid system. Nano Lett. 2016;16:5883-7.

103. Sultana S, Sahoo PC, Martha S, Parida K. A review of harvesting clean fuels from enzymatic CO, reduction. RSC Adv. 2016;6:44170-94.

104. Harnisch F, Schröder U. From MFC to MXC: chemical and biological cathodes and their potential for microbial bioelectrochemical systems. Chem Soc Rev. 2010;39:4433-48.

105. Freguia S, Virdis B, Harnisch F, Keller J. Bioelectrochemical systems: microbial versus enzymatic catalysis. Electrochim Acta. 2012;82:165-74.

106. Dominguez-Benetton X, Srikanth S, Satyawali Y, Pant KV, Pant D. Enzymatic electrosynthesis: an overview on the progress in enzyme- electrodes for the production of electricity, fuels and chemicals. J Microb Biochem Technol. 2013;6:007.

107. Reda T, Plugge CM, Abram NJ, Hirst J. Reversible interconversion of carbon dioxide and formate by an electroactive enzyme. Proc Natl Acad Sci. 2008;105:10654-8

108. Srikanth S, Maesen M, Dominguez-Benetton X, Vanbroekhoven K, Pant D. Enzymatic electrosynthesis of formate through $\mathrm{CO}_{2}$ sequestration/ reduction in a bioelectrochemical system (BES). Bioresour Technol. 2014;165:350-4
109. Addo PK, Arechederra RL, Waheed A, Shoemaker JD, Sly WS, Minteer SD. Methanol production via bioelectrocatalytic reduction of carbon dioxide: role of carbonic anhydrase in improving electrode performance. Electrochem Solid-State Lett. 2011;14:E9-13.

110. Srikanth S, Alvarez-Gallego Y, Vanbroekhoven K, Pant D. Enzymatic electrosynthesis of formic acid through carbon dioxide reduction in a bioelectrochemical system: effect of immobilization and carbonic anhydrase addition. ChemPhysChem. 2017. https://doi.org/10.1002/ cphc. 201700017.

111. Kim S, Kim MK, Lee $\mathrm{SH}$, Yoon S, Jung K-D. Conversion of $\mathrm{CO}_{2}$ to formate in an electroenzymatic cell using Candida boidinii formate dehydrogenase. J Mol Catal B Enzym. 2014;102:9-15.

112. Zhang L, Liu J, Ong J, Li SFY. Specific and sustainable bioelectroreduction of carbon dioxide to formate on a novel enzymatic cathode. Chemosphere. 2016;162:228-34

113. Bachmeier A, Hall S, Ragsdale SW, Armstrong FA. Selective visible-lightdriven $\mathrm{CO}_{2}$ reduction on a $p$-type dye-sensitized $\mathrm{NiO}$ photocathode. J Am Chem Soc. 2014;136:13518-21.

114. Lee SY, Lim SY, Seo D, Lee J-Y, Chung TD. Light-driven highly selective conversion of $\mathrm{CO}_{2}$ to formate by electrosynthesized enzyme/cofactor thin film electrode. Adv Energy Mater. 2016;6:1502207.

115. Kuk SK, Singh RK, Nam DH, Singh R, Lee J-K, Park CB. Photoelectrochemical reduction of carbon dioxide to methanol through a highly efficient enzyme cascade. Angew Chem Int Ed. 2017;56:3827-32.

116. Dibenedetto A, Stufano P, Macyk W, Baran T, Fragale C, Costa M, et al. Hybrid technologies for an enhanced carbon recycling based on the enzymatic reduction of $\mathrm{CO}_{2}$ to methanol in water: chemical and photochemical NADH regeneration. Chemsuschem. 2012;5:373-8.

117. Aresta M, Dibenedetto A, Baran T, Angelini A, Łabuz P, Macyk W. An integrated photocatalytic/enzymatic system for the reduction of $\mathrm{CO}_{2}$ to methanol in bioglycerol-water. Beilstein J Org Chem. 2014;10:2556-65.

118. Yadav RK, Oh GH, Park N-J, Kumar A, Kong K, Baeg J-O. Highly selective solar-driven methanol from $\mathrm{CO}_{2}$ by a photocatalyst/biocatalyst integrated system. J Am Chem Soc. 2014;136:16728-31.

119. Liu J, Cazelles R, Chen ZP, Zhou H, Galarneau A, Antonietti M. The bioinspired construction of an ordered carbon nitride array for photocatalytic mediated enzymatic reduction. Phys Chem Chem Phys. 2014;16:14699-705.

120. Yadav RK, Baeg J-O, Oh GH, Park N-J, Kong K, Kim J, et al. A photocatalyst-enzyme coupled artificial photosynthesis system for solar energy in production of formic acid from $\mathrm{CO}_{2}$. J Am Chem Soc. 2012;134:11455-61.

121. Yadav RK, Baeg J-O, Kumar A, Kong K, Oh GH, Park N-J. GrapheneBODIPY as a photocatalyst in the photocatalytic-biocatalytic coupled system for solar fuel production from $\mathrm{CO}_{2}$. J Mater Chem A 2014;2:5068-76.

122. Li Q, Guo B, Yu J, Ran J, Zhang B, Yan H, et al. Highly efficient visiblelight-driven photocatalytic hydrogen production of $\mathrm{CdS}$-cluster-decorated graphene nanosheets. J Am Chem Soc. 2011;133:10878-84.

123. Noji T, Jin T, Nango M, Kamiya N, Amao Y. $\mathrm{CO}_{2}$ photoreduction by formate dehydrogenase and a Ru-complex in a nanoporous glass reactor. ACS Appl Mater Interfaces. 2017;9:3260-5.

124. Abanades S, Flamant $G$. Thermochemical hydrogen production from a two-step solar-driven water-splitting cycle based on cerium oxides. Sol Energy. 2006;80:1611-23.

125. Bechthold I, Bretz K, Kabasci S, Kopitzky R, Springer A. Succinic acid: a new platform chemical for biobased polymers from renewable resources. Chem Eng Technol. 2008;31:647-54.

126. Xu J, Guzman JJL, Andersen SJ, Rabaey K, Angenent LT. In-line and selective phase separation of medium-chain carboxylic acids using membrane electrolysis. Chem Commun. 2015;51:6847-50.

127. Gildemyn S, Verbeeck K, Slabbinck R, Andersen SJ, Prévoteau A, Rabaey K. Integrated production, extraction, and concentration of acetic acid from $\mathrm{CO}_{2}$ through microbial electrosynthesis. Environ Sci Technol Lett. 2015;2:325-8. 